\title{
Productivity of Brachiaria decumbens in a Mixed-Culture with Pueraria phaseloides in Different Manure and Dolomite Administration Level into Suboptimal Land
}

\author{
Herdiawan I \\ ${ }^{1}$ Indonesian Research Institute of Animal Production, PO Box 221, Bogor Indonesia \\ E-mail: herdiawanmaliq@gmail.com
}

(received 27-09-2016; revised 07-11-2016; accepted 06-12-2016)

\begin{abstract}
ABSTRAK
Herdiawan I. 2016. Produktivitas Brachiaria decumbens dalam kultur campuran dengan Pueraria phaseloides dalam berbagai tingkat pupuk kandang dan dolomit di lahan suboptimal. JITV 21(4): 215-223. DOI: http://dx.doi.org/10.14334/jitv.v21i4/1562

Peningkatan produktivitas hijauan di lahan suboptimal dapat dilakukan dengan berbagai cara salah satu diantaranya melalui perlakuan pemupukkan dan amelioran. Pupuk kandang dan dolomit sangat dibutuhkan oleh tanah di lahan suboptimal, karena kombinasi keduanya dapat menyuplai unsur hara dan memperbaiki biofisik tanah. Materi penelitian yang digunakan adalah rumput $B$. decumbens, Pueraria phaseloides, pupuk kandang (Pukan), dan dolomit. Penelitian menggunakan rancangan Acak Kelompok pola faktorial 3x3, dosis pupuk kandang merupakan faktor pertama, dan dosis super dolomit merupakan faktor kedua, masing-masing perlakuan mendapat 3 ulangan. Peubah yang diamati adalah produksi biomassa, kapasitas tampung, dan kandungan nutrisi. Hasil penelitian menunjukkan bahwa produksi biomasa pada taraf perlakuan pukan 10 ton/ha dan super dolomit 2 ton/ha, nyata $(\mathrm{P}<0,05)$ paling tinggi sebesar $1.638,94 \mathrm{~g} / \mathrm{m}^{2}$ dibanding perlakuan lain dan terendah dicapai tanpa perlakuan (Kontrol), sebesar 543,75 g/ $\mathrm{m}^{2}$. Kapasitas tampung campuran B. decumbens dan $P$. phaseloides pada pukan 10 ton/ha nyata $(\mathrm{P}<0,05)$ paling tinggi sebesar 0,08 UT, dibandingkan dengan perlakuan pukan lain. Berdasarkan perlakuan dolomit, perlakuan dosis 1 ton/ha nyata $(\mathrm{P}<0,05)$ menghasilkan kapasitas tampung paling tinggi yaitu sebesar 0,83 UT. Mixed crop between B. decumbens and P. phaseloides in sub optimal land showed the highest forages quality and production when it was created with combination of $10 \mathrm{t} / \mathrm{ha}$ of manure and $2 \mathrm{t} / \mathrm{ha}$ of ameliorant. The manure and ameliorant treatment was also increasing the nutrient content of B. decumbens and P. phaseloides as well as land cacity.
\end{abstract}

Kata Kunci: Brachiaria decumbens, Pueraria phaseloides, Pupuk Kandang, Super Dolomit

\section{ABSTRACT}

Herdiawan I. 2016. Productivity of Brachiaria decumbens in a mixed-culture with Pueraria phaseloides in different manure and dolomite administration level into suboptimal land. JITV 21(4): 215-223. DOI: http://dx.doi.org/10.14334/jitv.v21i4/1562

Productivity improvement of forage in suboptimal land can be done in various ways, such as through manure and ameliorant treatment. Manure and dolomite is required by soil on suboptimal land, a combination of both can supply nutrients and improve soil biophysics. The research materials used in this study were B. decumbens, Pueraria phaseloides, manure, and dolomite. Randomized Block Design (RBD) in 3x3 factorial was applied. The dose of manure and dolomite are the first and second factors respectively, each treatment has 3 replications times. Variables measured were biomass production, dry matter production, carrying capacity, and nutrient content of forage. Results showed that the highest $(\mathrm{P}<0.05)$ biomass production produced by the $10 \mathrm{t} / \mathrm{ha}$ manure and $2 \mathrm{ton} / \mathrm{ha}$ dolomite treatment by $1,638.94 \mathrm{~g} / \mathrm{m}^{2}$ compared to the other treatments, and the lowest was achieved in the control by $543.75 \mathrm{~g} / \mathrm{m}^{2}$. Carrying capacity of $B$. decumbens and $P$. phaseloides on $10 \mathrm{ton} / \mathrm{ha}$ manure was the highest $(\mathrm{P}<0.05)$ by $0.08 \mathrm{AU}$ compared to the other treatments. Super dolomite administration by 1 ton/ha significantly $(\mathrm{P}<0.05)$ produced the highest carrying capacity by amount of $0.83 \mathrm{AU}$. Manure and dolomite administration significantly $(\mathrm{P}<0.05)$ improved the nutritional content of $B$. decumbens and $P$. phaseloides.

Key Words: Brachiaria decumbens, Pueraria phaseloides, Manure, Dolomite

\section{INTRODUCTION}

Fertilization and ameliorant administration are two kinds of attempt to improve the quality of soil in order to optimizeproductivity of crops. Organic fertilizer is a biological buffer to improve physical, chemical and biological properties of soil to provide balance nutrient (Kariada \& Aribawa 2005). Administration of manure and super dolomite to the growing media is one attempt to improve biophysical properties of soil in the suboptimal area. Super dolomite consists of two macrominerals which highly required by crops; calcium $(\mathrm{CaO})$ and Magnesium $(\mathrm{MgO})$. Magnesium and Calcium serve as enhancer nutrient, $\mathrm{pH}$ neutralizer, improving physical; biological and chemical properties of soil to increase the production (Sumaryo \& Suryono 
2000). Fertilization using organic material is indispensable, especially to supply soil nutrition, improving soil texture and biophysical (Parman \& Sarjana 2007). Kandil \& Gad (2010) reported that in the low fertility soil, fertilization using chicken manure might increase vegetative growth and quality of the harvest. Brachiaria humidicola grass is responsive to chicken manure administration, even in the second planting season (Kusuma 2015). Chicken manure level used were generally 10, 20, and 30 ton/ha (Luthfyrakhman \& Susila 2013). Cullison (1975) in Reksohadiprodjo (1994) described that carrying capacity is a pasture area, where it grows forage available for animal that grazed it as needed in a short time. So that, knowledge about the number of forage available in a pasture is important to determine its stocking. Assessment of total biomass of crop is a parameter used as an indicator of crop growth. The other reason in use of total biomass of crop is that DM of crop regarded as manifestation from all process and events occurred in the crop growth (Sitompul \& Guritno 1995).

Carrying capacity of pasture reflects balance between available forage and the animal unit shepherded per time unit (Rusdin et al. 2009). Whereas, Reksohadiprodjo (1985) described that carrying capacity is the capability of pasture to produce forage required by the number of animal shepherded in one hectare, or capability of pasture to accommodate animal per hectare. Carrying capacity may also be described as capability of pasture in accommodating the number of animal which may be maintained per wide area of the pasture (Subagyo \& Kusmartono 1988).

The carrying capacity is identic with the stocking rate as the number of animal (animal unit) per pasture area wide (Mudumi 1990). The carrying capacity is an analysis of the capability of a pasture area to accommodate a number of animals, so the grass requirement of animal for 1 year is fulfilled. The carrying capacity of pasture is closely related to kind of animal, grass production, season and pasture area. In other words, the carrying capacity varied depending on assessment of grass production. Grass production in the wet season will be higher than in the dry season which means there is more forage in the wet season. Damry (2009) said that wide area required to maintain one animal with $400 \mathrm{~kg}$ body weight was 14.4-15.5 ha/year and the ideal carrying capacity by $2.5 \mathrm{AU} / \mathrm{ha} / \mathrm{year}$.

\section{MATERIALS AND METHODS}

This study was conducted in Cibadak Sub-district, Lebak district, Province of Banten. Average rainfall was $1100 \mathrm{~mm} /$ year, temperature was $32-36^{\circ} \mathrm{C}$, humidity was $56-66 \%$, the soil type was acrisol, soil $\mathrm{pH}$ was 4.81 (BBSDLP 2015). Land area used was $5000 \mathrm{~m}^{2}$ divided into 27 plots $\left( \pm 185 \mathrm{~m}^{2}\right.$ each) of mixed B. decumbens $P$. phaseloides. Seed of $P$. phaseloides was from the seed sowed in the seedling for 4 weeks then was transferred into polybag until 8 weeks old and then was transferred to the field. Seed of B. decumbens was from pols planted in the polybag until 8 weeks old and then was transferred to the field. Simple soil processing: rotary plowing once, fertilizing, and super dolomite administration was conducted based on the treatment level. The watering was conducted from the beginning of planting until 6 weeks grew. Weedling was conducted every month. The first pruning of grass was conducted at 40 days after planting with harvest interval of 20 days, while at 60 days with harvest interval of 30 days . Observation was performed after the first pruning until the study ends.

Factorial Randomized Block Design (Gomez \& Gomez 1984) was applied in this study. The first factor was 3 level $(0,5$, and 10 ton/ha) manure administration. The second factor was 3 level $(0,1$, and 2 ton/ha) super dolomite administration. These treatents were repeated 3 times. Variables observed were fresh biomass production, nutrient content and carrying capacity. The fresh biomass production was obtained by weighing fresh grass/legume in every harvest. Nutrient content was analyzed proximately in laboratory of Nutrient of IRIAP-Ciawi. The carrying capacity used quadrant method (Alikodra 1990; Reksohadiprodjo 1996). Fifteen plots were selected randomly. Sampling was done using grass scissor of $1 \times 1$ quadrant as close as to the ground $( \pm 1.5 \mathrm{~cm})$. That grass was placed into envelope then weighed by $100 \mathrm{gr} / \mathrm{m} 2$. Those plots were selected by determining 1 point of the first plot, moved 10 steps to the right or left. Grass samples were put into paper bag to be analyzed in the laboratory later. Available forage production is total forage production produced by pasture (Dry Matter) reduced by production of weeds multiplied by proper use factor by $40-45 \%$ (Hariadi 2008). Land area requirement for 1 animal unit per year (ha/AU) was calculated by Voisin (1959) formula. Carrying capacity of pasture was calculated according to Abdullah (2009), assumed that $1 \mathrm{AU}$ is equal to $500 \mathrm{~kg}$ cattle with diet requirement per day (DM) was determined by $2.3-3 \%$ of body weight, and the stay period (grazing) for 70 days (Susetyo 1980). The simplest carrying capacity was calculated using a formula of Thorne \& Stevenson (2007):

Animal Unit month $=\underline{\text { DM Prod. } \mathrm{x} \text { pasture area }}$ DM requirement per month 


\section{RESULTS AND DISCUSSION}

\section{Fresh Biomass Production of B. decumbens in mixed-culture with $P$. phaseloides at different manure and ameliorant level}

There was an interaction between manure and dolomite administration level to fresh biomass production of $B$. decumbens and $P$. phaseloides. At the 10 ton/ha manure and 2 ton/ha dolomite administration resulted in the highest production by $1,638.94 \mathrm{~g} / \mathrm{m}^{2}$, where the lowest production was the control by 543.75 $\mathrm{g} / \mathrm{m}^{2}$.

Table 1. Fresh biomass production of $B$. decumbens in mixedculture with $P$. phaseloides at different manure and super dolomite $\left(\mathrm{g} / \mathrm{m}^{2}\right)$ level

\begin{tabular}{lccc}
\hline \hline Treatment & \multicolumn{3}{c}{ Ameliorant (super dolomite) (ton/ha) } \\
\hline Manure (ton/ha) & 0 & 1 & 2 \\
\hline 0 & $543.75^{\mathrm{e}}$ & $966.63^{\mathrm{d}}$ & $1,009.69^{\mathrm{d}}$ \\
5 & $910.94^{\mathrm{d}}$ & $1,462.50^{\mathrm{b}}$ & $1,205.00^{\mathrm{c}}$ \\
10 & $1,183.31^{\mathrm{c}}$ & $1,314.56^{\mathrm{bc}}$ & $1,638.94^{\mathrm{a}}$ \\
\hline
\end{tabular}

Description: Different words show significant difference $(\mathrm{P}<0.05)$.

Increased of manure and super dolomite level administration significantly increased fresh production of $B$. decumbens, except in the 5 ton/ha and 2 ton/ha level of manure and super dolomite, respectively. This proves that the $B$. decumbens is very responsive to fertilizer and the ameliorant. The gramineae, generally requires a fairly high $\mathrm{N}$, so the mixed culture system of legume with fertilizer and ameliorant administration will multiply $\mathrm{N}$ available in the soil. Manenetje \& Jones (1992) stated that Brachiaria brizantha, Brachiaria decumbens and Brachiaria humidicola were highly tolerant to acid soil and responsive to fertilizer consisting of $\mathrm{N}$; P; and $\mathrm{K}$, even though cannot stand the low drainage land. Winarso (2005) said that balance use of fertilizer would increase crop production. Abdurachman et al. (2000) reported that administration of any kind of manure of cattle, goat and chicken by 5 ton/ha in the Ultisol Jambi significantly increased organic-C level of soil and corn and soybean production. The administration of dolomite and cattle manure was expected to increase soil fertility, especially its physical and chemical properties improvement which will increase peanuts production (Rahmadani et al. 2012).

Padmowidjoto (2006) stated that development of mixed culture between legume and forage may improve environment and ecosystem condition, and as a result, improving the growth and increasing production of the crops. Translocation of $\mathrm{N}$ from legume to the surrounding crops influences its fertilization and increases its weight (Sirajuddin et al. 2010). The translocation of nutrient from the legume to the surrounding crops decreases mass of legume to be lower level than the one from the monoculture system. Patel \& Rajagopal (2003) said that the growth of legume planted intercropping was not better than legume planted monoculture, and on the contrary. This is allegedly that legume does not get additional nutrients from the host crop, indeed the nutrients required by legume are absorbed by the host crop, resulting in low production of legume.

Gardner et al. (2008) said that in the mixed culture system, legume donated $\mathrm{N}$ to the grass during its growth period resulting in higher biomass production compared to the monoculture system. Legume is crop that has ability to produce high organic material and may improve soil fertility. Its ability to fix/grab $\mathrm{N}$ from the air may increase nutrient supply for the surrounding crops, especially the N. Soedomo (1981) stated that there was a translocation of $\mathrm{N}$ from legume to grass by around $0-53 \%$ from the fixated $\mathrm{N}$ through fallen legume leaves, rotten root and nodule. Nulik et al. (2013) said that $\mathrm{N}$ was also available for the surrounding through the decomposition of root and leaves. The crops planted along with or after legume has potential of higher productivity due to higher chance to access $\mathrm{N}$, however, this is highly dependent to management of legume and high biomass number. Symbiosis of legume and rhizombium is able to fixate $\mathrm{N}$ from the air to fulfill $\mathrm{N}$ requirement of the host and its surrounding crops (Islami \& Utomo 1995; Hidayati et al. 2001).

\section{Carrying capacity of mixed $B$. decumbens - $P$. phaseloides at different fertilizer and ameliorant level}

Analysis of variance showed an interaction between manure and supernatant dolomite level to the carrying capacity of the mixed B. Decumbens - P. phaseloides.

Carrying capacity of 5 ton/ha manure plus 1 ton/ha administration and 10 ton/ha manure plus 2 ton/ha super dolomite showed significant different $(\mathrm{P}<0.05)$ compared to the other treatment level. The 0 ton/ha manure and super dolomite level showed the lowest carrying capacity. The carrying capacity closely connects with biomass production and dry material content of crops, as of in 5 ton/ha manure plus 1 ton/ha super dolomite level, and 10 ton/ha manure plus 1 ton/ha super dolomite showed biomass production and higher dry material compared to the other treatment level. As stated by Santosa (1995) that higher production level of crop per one unit area increased its ability to accommodate a number of animal. Increase of grass production per one unit area is not apart from effect of legume crops which was planted along, 
because generally $\mathrm{N}$ content of legume may be transferred both into soil and crops directly. Besides, there was an increase of dry matter of crops in mixedculture due to high dry matter contribution from legume. Dhalika et al. (2006) stated that legume played a critical role in increasing pasture productivity due to its capability in fixing a number of nitrogen in the air. Its direct contribution to crop productivity through provision of forage resource rich in nitrogen.

In the mixed-culture of grass and legume in one area, legume that may produce $\mathrm{N}_{2}$ through fixation process of $\mathrm{N}_{2}$ from the air with the help of Rhizobium, indirectly may supply $\mathrm{N}$ requirement of its surrounding crops. The $\mathrm{N}$ produced by the legume will be used by the surrounding for metabolic process which increases dry material level of the crops. As stated by Murbandono (2001) that manure fertilizer is crucial to enrich soil nutrient. Sutejo (2002) stated that nutrient in the soil in the form of $\mathrm{N}, \mathrm{P}$, and $\mathrm{K}$, may be used in the form of anion and cation.

\section{Nutrition content of $B$. decumbens in mixed culture with $\boldsymbol{P}$. phaseloides at different manure and amelioran level}

The statistical analysis showed no interaction between manure and ameliorant level toward dry material of $B$. decumbens. Combination of 5 ton/ha manure and 1 ton/ha ameliorant resulted in the highest dry matter by $22.51 \%$. The lowest DM content of $B$. decumbens by $16 \%$ was in the control.

Fertilization is one-factor affecting nutrient value of the forage (McDonald et al. 2002). Ifradi et al. (1998) stated that manure administration would increase dry material, protein and decrease crude fiber. Rosmarkam \& Yuwono (2002) stated that fertilization using nitrogen would increase production and total DM of crops. Besides, Reksohadiprodjo (1994) also described that mixed culture of grass and legume was better than grass planted monoculture, as in addition to having protein, legume also has higher phosphor and calcium.
Susanti (2007) reported that DM content of elephant grass with fertilization was higher than without fertilization.

Research result showed that there was interaction between manure and ameliorant level toward crude protein of $B$. decumbens. Increase of manure and ameliorant level administration was followed by increase of crude protein content. The highest crude protein content was in the 10 ton/ha manure and 2 ton/ha ameliorant administration.

As reported by Sarief (1986) that the decrease of $\mathrm{N}$ in the soil would decrease protein level and increase ratio of protoplasm and cell wall thickening the cell wall resulting in hard and fibrous leaves. Minson (1990) also said that content and composition of crude protein in forage were influenced by nitrogen availability in the soil solution. Crude protein content of grass is highly dependent to the concentration of available $\mathrm{N}$ in the soil. Administration of manure means administrating optimum $\mathrm{N}$ which can be absorbed by crops. Kaunang (2005) stated that fertilization might increase protein content of forage. Protein of forage will be degraded and fermented into ammonia, volatile fatty acid, $\mathrm{CO}_{2}$ and $\mathrm{CH}_{4}$. Valentin et al. (1988) reported that mixed culture of elephant grass and Arachis glabrata without $\mathrm{N}$ fertilization might increase crop production more than $100 \%$ and increased protein about $200 \%$ compared to grass planted monoculture. Kaunang (2005) in Marliani (2010) stated that content and composition of crude protein in forage were influenced by availability of nitrogen in the soil that inhibiting synthesis process in the forage. Mixed culture system of grass and legume (legume were planted along with grass for the sake of the grass) increased nutrient of the pasture compared to the monoculture system, as a result of high content of nitrogen and calcium in the legume (Suharta 2010). Engelstad (1997) stated that optimal nitrogen administration might improve crop growth and increase protein synthesis. This is clarified by Crespo \& Odurado (1986) who said that efficiency of nitrogen conversion increased along with increase of $\mathrm{N}$

Table 2. Carrying capacity of mixed B. decumbens - P. phaseloides at different manure and super dolomite (UT) level

\begin{tabular}{|c|c|c|c|c|}
\hline \multirow{2}{*}{$\frac{\text { Treatment }}{\text { Manure (ton/ha) }}$} & \multicolumn{3}{|c|}{ Ameliorant super dolomite (ton/ha) } & \multirow{2}{*}{ Average } \\
\hline & 0 & 1 & 2 & \\
\hline 0 & $0,27^{\mathrm{e}}$ & $0,57^{\mathrm{d}}$ & $0,57^{\mathrm{d}}$ & 0,47 \\
\hline 5 & $0,58^{\mathrm{d}}$ & $0,99^{\mathrm{a}}$ & $0,80^{\mathrm{b}}$ & 0,79 \\
\hline 10 & $0,77^{\mathrm{c}}$ & $0,92^{\mathrm{b}}$ & $0,94^{\mathrm{a}}$ & 0,88 \\
\hline Average & 0,54 & 0,83 & 0,77 & \\
\hline
\end{tabular}

Description: Different words show significant difference $(\mathrm{P}<0.05)$. 
Herdiawan. Productivity of Brachiaria decumbens in a mixed-culture with Pueraria phaseloides in different manure and dolomite

Table 3. Content of Dry Material (DM) of B. decumbens planted along with $P$. phaseloides at different manure and ameliorant level $(\%)$

\begin{tabular}{lcccc}
\hline \hline Treatment & \multicolumn{3}{c}{ Ameliorant (super dolomite) (ton/ha) } & \multirow{2}{*}{ Average } \\
\cline { 1 - 3 } Manure (ton/ha) & 0 & 1 & 17.40 & $17.04^{\mathrm{c}}$ \\
\hline 0 & 16.00 & 17.72 & 20.04 & $20.74^{\mathrm{a}}$ \\
5 & 19.68 & 22.51 & 19.50 & $19.90^{\mathrm{b}}$ \\
10 & 19.69 & 20.51 & $19.23^{\mathrm{b}}$ & \\
Average & $18.46^{\mathrm{c}}$ & $20.25^{\mathrm{a}}$ & & \\
\hline
\end{tabular}

Description: Different words show significant difference $(\mathrm{P}<0.05)$.

fertilization increasing crude protein content. Research result showed no interaction between manure and ameliorant treatment to the crude fiber content. The highest crude fiber content by $31.16 \%$ was in the control (without manure ) and the lowest one was in the 5 ton/ha manure level by $27.96 \%$. The highest crude fiber was in the control (without ameliorant ) by $31.43 \%$ and the lowest was in the 1 ton/ha ameliorant administration by $27.83 \%$.

Ifradi et al. (1998) said that manure administration would increase dry matter and protein and decreasing crude fiber. Sarief (1986) described that decrease of $N$ in the soil would decrease protein level and increasing ratio of protoplasm and cell wall thickening cell wall resulting hard and fibrous leaves. DM and CF content tend to increase along with increase of age of the forage and decrease of fertilization level. Allegedly, as a result of the $\mathrm{N}$ which is highly mobile in the soil may facilitate the root to absorb water in the soil. That causes lots of water content in the crops that may hamper lignification in the crops. Then, aging leads crops to renaissance phase, where the crops are in the aging period producing high cellulose and lignin.

There was no interaction between treatment level and ameliorant to energy content of $B$. decumbens in this study. The highest energy content of $B$. decumbens was in the 10 ton/ha manure administration by 4011 $\mathrm{Kkal} / \mathrm{kg}$ and the lowest was in the control (without manure) by $3999 \mathrm{Kkal} / \mathrm{kg}$. Administration of ameliorant by 2 ton/ha produced the highest energy content by $4021 \mathrm{Kkal} / \mathrm{kg}$ and the lowest one was in the $1 \mathrm{ton} / \mathrm{ha}$ ameliorant administration by $3994 \mathrm{Kkal} / \mathrm{kg}$. Nuhuyanan

Table 4. Crude Protein content of B. decumbens in mixed culture with $P$. phaseloides at different manure and ameliorant level (\%)

\begin{tabular}{lcccc}
\hline \hline Treatment & \multicolumn{2}{c}{ Ameliorant (super dolomite) (ton/ha) } & \multicolumn{2}{c}{ Average } \\
\cline { 1 - 2 } Manure (ton/ha) & 0 & 1 & 2 & 11.51 \\
\hline 0 & $10.02 \mathrm{~d}$ & $11.82 \mathrm{c}$ & $12.70 \mathrm{~b}$ & 12.29 \\
5 & $11.05 \mathrm{c}$ & $12.07 \mathrm{~b}$ & $13.76 \mathrm{a}$ & 13.15 \\
10 & $12.14 \mathrm{~b}$ & $13.52 \mathrm{a}$ & $13.80 \mathrm{a}$ & \\
Average & 11,07 & 12,47 & 13,42 & \\
\hline
\end{tabular}

Description: Different words show significant difference $(\mathrm{P}<0.05)$.

Table 5. Crude Fiber content of $B$. decumbens in mixed culture with $P$. phaseloides at different manure and ameliorant level (\%)

\begin{tabular}{|c|c|c|c|c|}
\hline \multirow{2}{*}{$\begin{array}{l}\text { Treatment } \\
\text { Manure (ton/ha) }\end{array}$} & \multicolumn{3}{|c|}{ Ameliorant (super dolomite) (ton/ha) } & \multirow{2}{*}{ Average } \\
\hline & 0 & 1 & 2 & \\
\hline 0 & 37.13 & 27.75 & 29.92 & $31.16 \mathrm{a}$ \\
\hline 5 & 25.94 & 26.13 & 31.80 & $27.96 \mathrm{c}$ \\
\hline 10 & 31.17 & 29.62 & 30.25 & $30.35 \mathrm{ab}$ \\
\hline Average & $31.43 \mathrm{a}$ & $27.83 \mathrm{c}$ & $30.66 \mathrm{ab}$ & \\
\hline
\end{tabular}

Description: Different words show significant difference $(\mathrm{P}<0.05)$. 
(2010) reported that fertilization and legume introduction provided better effect to in vitro digestibility of DM, OM, TDN and EM of grass compared to the without introduction of legume and fertilizing.

Research results showed no interaction between manure and ameliorant level to Calcium $(\mathrm{Ca})$ content of $B$. decumbens. The highest $\mathrm{Ca}$ content was in the 5 and 10 ton/ha manure by $24 \%$ each and the lowest was in the control (without manure administration) by $0.23 \%$.

The administration of ameliorant by 2 ton/ha showed the highest $\mathrm{Ca}$ content by $0.25 \%$, while the lowest one was in the control (without ameliorant administration) by $0.23 \%$. Dhalika et al. (2006) stated that counterweight mixed culture of grass and legume significantly increased $\mathrm{Ca}$ content of forage. Legume, as calcium source is able to provide $\mathrm{Ca}$ for its surrounding crops (Reksohadiprodjo 1994). Hartadi et al. (1990) also said that calcium content in the Sentro was $1.19-1.26 \%$ depending on crops age. The older crops have higher calcium, while the calcium content of Cynodon plectosthacyus is only $0.3 \%$. Ayub et al. (2004) stated that absorption rate of $\mathrm{Ca}$ and $\mathrm{P}$ by forage planted intercropping would be higher than the monoculture, impact on the production and nutrient quality of the mixed-forage.

The highest phosphor $(\mathrm{P})$ content was achieved in the 10 ton/ha manure by $0.19 \%$ and the lowest one was without manure by $0.15 \%$. The highest Phosphor content was in 2 ton/ha ameliorant by $0.19 \%$, while the lowest one was without ameliorant by $0.16 \%$. Hartadi et al. (1990) reported that phosphor content of African grass was $0.31 \%$, while in the Centro legume was around $0.40 \%$. Phosphor content of forage in the monoculture system of grass is $0.23 \%$, whereas in the legume planted monoculture is $0.34 \%$. It shows that phosphor content in the grass planted monoculture is.

Table 6. Energy content of $B$. decumbens planted along with $P$. phaseloides at different manure and amelioran level (Kkal $/ \mathrm{kg})$

\begin{tabular}{|c|c|c|c|c|}
\hline \multirow{2}{*}{$\frac{\text { Treatment }}{\text { Manure (ton/ha) }}$} & \multicolumn{3}{|c|}{ Amelioran (super dolomite) (ton/ha) } & \multirow{2}{*}{ Average } \\
\hline & 0 & 1 & 2 & \\
\hline 0 & 4005 & 3985 & 4007 & $3999^{c}$ \\
\hline 5 & 3989 & 3978 & 4059 & $4009^{b}$ \\
\hline 10 & 4019 & 4018 & 3996 & $4011^{\mathrm{a}}$ \\
\hline Average & $4004^{b}$ & $3994^{c}$ & $4021^{\mathrm{a}}$ & \\
\hline
\end{tabular}

Description: Different words show significant difference $(\mathrm{P}<0.05)$.

Table 7. Ca content of $B$. decumbens in mixed culture with $P$. phaseloides at different manure and ameliorant level (\%)

\begin{tabular}{llccc}
\hline \hline Treatment & \multicolumn{2}{c}{ Ameliorant (super dolomite) (ton/ha) } & \multirow{2}{*}{ Average } \\
\cline { 1 - 3 } Manure (ton/ha) & 0 & 1 & 2 & $0.23^{\mathrm{b}}$ \\
\hline 0 & 0.21 & 0.23 & 0.26 & $0.24^{\mathrm{a}}$ \\
5 & 0.24 & 0.23 & 0.23 & $0.24^{\mathrm{a}}$ \\
10 & 0.23 & 0.27 & $0,25^{\mathrm{a}}$ & \\
Average & $0,23^{\mathrm{c}}$ & $0,24^{\mathrm{b}}$ & \\
\hline
\end{tabular}

Description: Different words show significant difference $(\mathrm{P}<0.05)$

Table 8. Phosphor $(\mathrm{P})$ content of $B$. decumbens in mixed culture with $P$. phaseloides at different manure and ameliorant level (\%)

\begin{tabular}{lcccc}
\hline \hline Treatment & & Ameliorant (super dolomite) (ton/ha) & & 2 \\
\hline Manure (ton/ha) & 0 & 1 & 0.14 & $0.15^{\mathrm{c}}$ \\
\hline 0 & 0.17 & 0.15 & 0.22 & $0.18^{\mathrm{b}}$ \\
5 & 0.15 & 0.16 & 0.20 & $0.19^{\mathrm{a}}$ \\
10 & 0.15 & $0.18^{\mathrm{b}}$ & $0.19^{\mathrm{a}}$ \\
\hline
\end{tabular}

Description: Different words show significant difference $(\mathrm{P}<0.05)$. 
very poor which allegedly has slightly contributed to the amount of phosphor of the mixed-culture crops

The increase of phosphor content of crops in the mixed legume and grass culture is the phosphor contributed by the legume. The increase of legume proportion in the mixed legume and grass culture produces higher phosphor. The highest phosphor content in the mixed-culture system was achieved by mixed $20 \%$ grass and $80 \%$ legume, but still lower than phosphor content of crop planted monoculture (Dhalika et al. 2006). Ayub et al. (2004), stated that quality, biomass production, and $\mathrm{Ca}, \mathrm{P}$ consentration in intercropping forages were higher compared to monoculture.

Analysis of variance showed no interaction between manure and ameliorant to the digestibility of $B$. decumbens by in vitro. Manure level by 0 ton/ha showed the highest digestibility value by $59.65 \%$, whereas manure level by 10 ton/ha showed the lowest digestibility value by $44.65 \%$. Ameliorant level by 2 ton/ha showed the highest digestibility value by 58.74 , whereas ameliorant level by 0 ton/ha showed the lowest digestibility value by $45.33 \%$.

Dry matter digestibility consists of organic and inorganic materials which can be digested. Inorganic material consists of minerals, while the organic material consists of compounds of nitrogenous, carbohydrate, fat and vitamins. Digestibility of dry matter is influenced by lignin concentration (Purbajanti et al. 2011). Nitrogen plays role in growth promoting of crops in the vegetative period, chlorophyll forming and as component that forms fat, protein and other organic compounds (Mengel \& Kirkby 2001). Nitrogen also specifically influences digestibility of forage. Research result of Ningsih (2007) showed that digestibility of elephant grass (Pennisetum purpureum cv. Taiwan) grew in the Ultisol soil was around $64.72 \%$ up to $65.33 \%$. The amount of nutrients absorbed by crops will increase photosynthesis that increasing the amount of carbohydrate produced by crops which then supports stems and leaves forming (Lakitan 1996). This will influence the value and amount of digested dry matter. Digested dry matter, mostly consists of digested organic material (protein, fat and carbohydrate) (Ifradi et al. 2012).

Analysis of variance showed no interaction between manure and ameliorant level with organic matter digestibility value of the $B$. decumbens by in-vitro. Van Soest et al. (1982) stated that nitrogen (N) may increase the cell content due to the association of $\mathrm{N}$ with carbon chain to prevent cell wall forming as well as increasing cell content. This implicates increase of forage digestibility.

Coefficient value of digestibility of dry matter or organic matter shows digestibility level of diet in digestive tract and how much contribution of a diet for animal (McDonald et al. 2002). The organic matter digestibility related to chemical composition of forage $(\mathrm{N}$, ash, eter extract, cell wall, ADF, ADL, silica, where

Table 9. Digestibility Value of Dry Material of B. decumbens in mixed culture with P. phaseloides at different manure and ameliorant level (\%)

\begin{tabular}{lcccc}
\hline \hline Treatment & \multicolumn{2}{c}{ Ameliorant (super dolomite) (ton/ha) } & \multirow{2}{*}{ Average } \\
\cline { 1 - 3 } Manure (ton/ha) & 0 & 1 & 2 & \\
\hline 0 & 63.50 & 63.86 & 51.59 & $59.65^{\mathrm{a}}$ \\
5 & 44.44 & 51.38 & 61.51 & $52.44^{\mathrm{b}}$ \\
10 & -28.06 & 42.78 & 63.11 & $44.65^{\mathrm{c}}$ \\
Average & $45,33^{\mathrm{c}}$ & $52,67^{\mathrm{b}}$ & $58,74^{\mathrm{a}}$ & \\
\hline
\end{tabular}

Description: Different words show significant difference $(\mathrm{P}<0.05)$

Table 10.Digestibility Value of Organic Materil of B. decumbens in mixed culture P. phaseloides at different manure and ameliorant level $(\%)$

\begin{tabular}{lcccc}
\hline \hline Treatment & \multicolumn{2}{c}{ Ameliorant (super dolomite) (ton/ha) } & \multicolumn{2}{c}{ Average } \\
\cline { 1 - 3 } Manure (ton/ha) & 0 & 1 & 48.22 & $57.97^{\mathrm{a}}$ \\
\hline 0 & 61.56 & 64.13 & 61.23 & $49.32^{\mathrm{b}}$ \\
5 & 42.44 & 44.28 & 60.20 & $40.41^{\mathrm{c}}$ \\
10 & -23.60 & -37.43 & $56,55^{\mathrm{a}}$ & \\
Average & $42,53^{\mathrm{c}}$ & $48,61^{\mathrm{b}}$ & \\
\hline
\end{tabular}

Description: Different words show significant difference $(\mathrm{P}<0.05)$. 
the increase of percentage of those cell wall, ADL, silica, and eter extract will decrease digestibility of organic matter of forage (Muir et al. 2003). Suyitman (2003) stated that organic matter content of elephant grass (Pennisetum purpureum) cv. Taiwan was around $84.20-89.90 \%$ and will increase along with fertilizing. Sutardi (1980) said that the increase of dry matter increased organic matter digestibility since the dry matter is directly proportional to the organic matter digestibility.

\section{CONCLUSION}

Mixed crop between $B$. decumbens and $P$. phaseloides in sub optimal land showed the highest forages quality and production when it was created with combination of $10 \mathrm{t} / \mathrm{ha}$ of manure and $2 \mathrm{t} / \mathrm{ha}$ of ameliorant. The manure and ameliorant treatment was also increasing the nutrient content of $B$. decumbens and $P$. phaseloides as well as land capacity.

\section{REFERENCES}

Abdullah L. 2009. Pola pertumbuhan rumput signal (Brachiaria humidicola (Rendle) Schweick) pada padang penggembalaan dengan aplikasi sumber nutrien berbeda. Bogor (Indones): Fakultas Peternakan, Institut Pertanian Bogor.

Abdurachman A, Juarsah I, Kurnia U. 2000. Pengaruh pengunaan berbagai jenis dan takaran pupuk kandang terhadap produktivitas tanah Ultisols terdegradasi di Desa Batin, Jambi. Prosiding Seminar Nasional Sumber Daya Tanah, Iklim dan Pupuk. Bogor (Indones): Pusat Penelitian Tanah dan Agroklimat.

Alikodra HS. 1990. Pengelolaan satwa liar. Jilid I. Bogor (Indones): Departemen Pendidikan dan Kebudayaan. Direktorat Jendral Perguruan Tinggi. Pusat Antar Universitas Ilmu Hayat. Institut Pertanian Bogor.

Ayub M, Tanveer A, Nadeem MA, Shah SMA. 2004. Studies on the fodder yield and quality of sorghum grown alone and in mixture with rice bean. Pak J Life Social Sci. 2:46-46.

Cullison AE. 1975. Feeds and feeding. Virginia (USA): Reston Publishing Inc.

Dhalika T, Mansyur, Mustafa HK, Supratman H. 2006. Imbangan rumput Afrika (Cynodon Plectostachyus) dan Leguminosa Sentro (Centrosema Pubescans) dalam sistem pastura campuran terhadap produksi dan kualitas hijauan. Jurnal Ilmu Ternak. 6:163-168.

Gomez KA, Gomez AA. 1984. Statistical procedures for agricultural research. 2nd ed. Los Banos (Philiphines): University of the Philiphines at Los Banos. p. 139-154.

Gardner FP, Pearce RB, Mitchell RL. 2008. Fisiologi tanaman budidaya. Jakarta (Indones): Universitas Indonesia.
Hartadi H, Reksohadiprodjo S, Tillman D. 1990. Tabel komposisi makanan untuk Indonesia. Yogyakarta (Indones): Gadjah Mada University Press.

Hariadi BT. 2008. Pendugaan daya tampung Walabi Lincah (Macropus agilis) di padang rumput Mar Taman Nasional Wasur Merauke. J Ilmu Peternakan. 3:58-63.

Hidayati N, Talib C, Pohan A. 2001. Produktivitas padang penggembalaan rumput alam untuk menghasilkan sapi bibit di Kupang Timur, Nusa Tenggara Timur. Dalam Haryanto B, Setiadi B, Sinurat AP, Mathius IW, Situmorang P, Nurhayati, Ashari, Abubakar, Murdiati TB, Hastiono S, Hardjoutomo S, Abdul Adjid RM, Priadi A,. Prosiding Seminar Nasional Teknologi Peternakan dan Veteriner 2001. [Bogor (Indones)]: Pusat Penelitian dan Pengembangan Peternakan. Hlm. 345-350.

Ifradi, Peto M, Fitriana E. 1998. Pengaruh pemberian pupuk dan mulsa jerami terhadap produksi dan nilai gizi rumput raja pada tanah Podsolik Merah Kuning, J Penel Andalas. 10:26-30.

Ifradi, Evitayani, Fariani A, Warly L, Suyitman, Yani S, Emikasmira. 2012. Pengaruh dosis pupuk N, P dan K terhadap kecernaan secara in vitro rumput gajah (Pennisetum purpureum) cv. Taiwan yang di inokulasi CMA Glomus manihotis pada lahan bekas tambang batubara. J Pet Indonesia. 14:279-285.

Islami T, Utomo WH. 1995. Hubungan tanah, air dan tanaman. Semarang (Indones): IKIP Semarang Press.

Kandil H, Gad N. 2010. Response of tomato plants to sulphur and organik fertilizer. Int J Academic Res. 2:204-210.

Kariada LK, Aribawa LB. 2005. Pengaruh residu jenis dan dosis pupuk organik terhadap pertumbuhan dan hasil padi di Subak Rejasa Kabupaten Tabanan Bali. Bali (Indones): BPTP Bali.

Kaunang LC. 2005. Respon ruminan terhadap pemberian hjiauan pakan yang dipupuk air belerang (Disertasi). [Bogor (Indones)]: Institut Pertanian Bogor.

Kusuma ME. 2015. Pengaruh Lanjutan Dosis Pupuk Kotoran Ternak Ayam Terhadap Pertumbuhan dan Produksi Rumput Brachiaria humidicola pada Pemotongan Kedua. Jurnal Ilmu Hewani Tropika.4:49-52.

Lakitan B. 1996. Fisiologi pertumbuhan dan perkembangan tanaman. Jakarta (Indones): Rajawali Pers.

Luthfyrakhman H, AD Susila. 2013. Optimasi Dosis Pupuk Anorganik dan Pupuk Kandang Ayam pada Budidaya Tomat Hibrida (Lycopersicon esculentum Mill. L.). Bul. Agrohorti 1 (1) : 119 - 126

Manenetje L't, Jones RM. 1992. Prosea. Plant Resources of South-East Asia. No. 4. Forages. Bogor (Indones): Prosea Foundation,

Marliani. 2010. Produksi dan kandungan gizi rumput Setaria (Setaria sphacelata) pada pemotongan pertama yang ditanam dengan jenis pupuk kandang berbeda (Skripsi). [Riau (Indones)]: Universitas Islam Negeri Sultan Syarif Kasim. 
Mcdonald P, Edwards RA, Greenhalg JFD, Morgan CA. 2002. Animal Nutrition. 6th ed. Gosport (...): Ashford Color Press.

Mengel K, Kirkby EA. 2001. Principles of plant nutrition. 5th Edition. Dordrecht, Boston, London: Kluwer Academic Publishers. p. 849

Mudumi. 1990 Pengelolaan padang pengembalaan dalam upaya peningkatan produksi pakan (Skripsi). Manokwari (Indones): Universitas Cenderawasih.

Muir JP, Ocumpaugh WR, Read JC. 2003. Spring forage yield and nutritive value of Texas black medic accessions. Agron J. 95:908-912.

Ningsih W. 2007. Pengaruh dosis pupuk N, P, dan K dan inokulasi CMA Glomus manihotis pada tanah ultisol rumput gajah (Pennisetum purpureum) cv. Taiwan pemotongan pertama terhadap kecernaan $\mathrm{BK}, \mathrm{BO}$, dan PK secara In-Vitro (Skripsi). [Padang (Indones)]: Fakultas Peternakan, Universitas Andalas.

Murbandono L. 2001. Membuat kompos. Jakarta (Indonesia): Penebar Swadaya.

Nuhuyanan LE. 2010. Pengaruh pemupukan dan introduksi legum terhadap kualitas padang rumput alam di Kebar Kabupaten Manokwari. Jurnal Ilmu Peternakan. 5:13-19.

Nulik J, Dalgliesh N, Cox K, Gabb S. 2013. Mengintegrasikan legum herba ke dalam system tanaman dan ternak di Indonesia bagian timur. ACIAR Monograph No. 154a. Canberra (Australia): Australian Centre for International Agricultural Research. p. 130.

Padmowidjoto S. 2006. Integrasi legum dengan tanaman pangan dan ternak kambing dalam usahatani sistem. Prospect. 2:1-4.

Parman, Sarjana. 2007. Pengaruh pemberian pupuk organik cair terhadap pertumbuhan dan produksi kentang (Solanum tuberosum L.). Buletin Anatomi dan Fisiologi. Vol. XV(2) p.21-31.

Patel JR, Rajagopal S. 2003. Nitrogen Management of Sorghum (Sorghumbicolor) and cowpea (Vigna unguiculata) forage under intercropping system. Indian J Agronom. 48:34-37.

Purbajanti ED, Soetrisno ED, Hanudin E, Sasmito SP, Budhi. 2011. Produksi, kualitas dan kecernaan in vitro tanaman rumput Benggala (Panicum maximum) pada lahan salin. Buletin Peternakan. 35:30-37.

Rahmadani E, Mulyani A, Sunarlim N. 2012. Performan sifat vegetatif, komponen hasil, dan hasil berbagai varietas kacang hijau (Vigna radiataL.) di media gambut. J Agroteknologi. 2:7-14.

Reksohadiprodjo S. 1996. Kualitas dan produktivitas hijauan pakan di Indonesia. Makalah Seminar Nasional Hijauan Pakan. Bogor.

Reksohadiprodjo S. 1994. Produksi hijauan makanan ternak. Yogyakarta (Indones): Badan Penerbitan Fakultas Ekonomi (BPFE) Universitas Gajah Mada.
Reksohadiprodjo S. 1985. Produksi tanaman hijauan makanan ternak tropika. Yogyakarta (Indones): BPFE.

Rosmarkam A, Yuwono NW. 2002. Ilmu kesuburan tanah. Yogyakarta (Indones): Penerbit Kanisius.

Rusdin MI, Mustaring, Purwaningsih S, Atik A, Sri UD. 2009. Studi potensi kawasan Lore Tengah untuk pengembangan sapi potong. Media Litbang Sulteng. 2:94-103.

Santosa U. 1995. Tata laksana pemeliharaan ternak sapi. Jakarta (Indones): Penebar Swadaya.

Sarief ES. 1986. Kesuburan dan pemumanure tanah pertanian. Bandung (Indones): Pustaka Buana.

Sirajuddin M, Sri AL. 2010. Respon pertumbuhan dan hasil jagung manis (Zea mays saccharata) pada berbagai waktu pemberian pupuk nitrogen dan ketebalan mulsa jerami. J Agroland. 17:184-191.

Sitompul SM, Guritno B. 1995. Analisis pertumbuhan tanaman. Yogyakarta (Indones): Gadjah Mada University Press.

Soedomo R. 1985. Produksi tanaman hijauan makanan ternak tropik. Jakarta (Indones): PT Gramedia.

Subagyo I, Kusmartono. 1988. Ilmu kultur padangan. Nuffic. Malang (Indones): Universitas Brawijaya.

Sumaryo, Suryono. 2000. Pengaruh dosis pupuk dolomit dan SP-36 terhadap jumlah bintil akar dan hasil tanaman kacang tanah di tanah latosol. J Agrosains. 2:54-58.

Susanti S. 2007. Produksi dan kecernaan in vitro rumput Gajah pada berbagai imbangan pupuk Nitrogen dan Sulfur. Buana Sain. 7:151-156.

Susetyo B. 1980. Padang penggembalaan. Bogor (Indones): Departemen Ilmu Makanan Ternak, Fakultas Peternakan, Institut Pertanian Bogor.

Sutardi T. 1980. Ternak perah dan pemberian makanannya. Edisi ke-1. Bogor (Indones): Departemen Ilmu Makanan Ternak, Fakultas Peternakan, Institut Pertanian Bogor.

Thorne MS, Stevenson MH. 2007. Stocking rate: The most important tool in the toolbox. Pasture and Range Management. Honolulu, Hawaii (USA): College of Tropical Agriculture and Human Resources, University of Hawai'i. p. 1-10.

Valentin F, Ruet OC, Pram GM. 1988. Evaluation of forage yield, quality, and botanical composition of a dwarfelephangrass - rhizoma peanut association as affected by nitrogen fertilization. Soil and Crop Sci. Soc. FIa.Proc. 47:237-242 .

Van Soest PJ. 1982. Nutritional ecology of the ruminant. New York (USA): Cornell University Press.

Voisin A. 1959. Grass productivity. California (USA): Island Press.

Winarso S. 2005. Kesuburan tanah, dasar kesehatan dan kualitas tanah. Yogyakarta (Indones): Gava Media. 